\title{
In Vivo Non-radioactive Assessment of mGlu5 Receptor-Activated Polyphosphoinositide Hydrolysis in Response to Systemic Administration of a Positive Allosteric Modulator
}

\author{
Anna R. Zuena', Luisa lacovelli', Rosamaria Orlando'1, Luisa Di Menna², Paola Casolini', \\ Giovanni Sebastiano Alemà', Gabriele Di Cicco', Giuseppe Battaglia² ${ }^{2}$ and \\ Ferdinando Nicoletti ${ }^{1,2 *}$ \\ 'Department of Physiology and Pharmacology "Vittorio Erspamer," Sapienza University, Rome, Italy, ${ }^{2}$ IRCCS Neuromed, \\ Pozzilli, Italy
}

OPEN ACCESS

Edited by:

M. Foster Olive

Arizona State University, United States

Reviewed by: Karen K. Szumlinski,

University of California, Santa Barbara, United States

Andrzej Pilc,

Polish Academy of Sciences, Poland

*Correspondence:

Ferdinando Nicolett ferdinandonicoletti@hotmail.com

Specialty section: This article was submitted to

Neuropharmacology,

a section of the journal Frontiers in Pharmacology

Received: 09 May 2018 Accepted: 03 July 2018

Published: 31 July 2018

Citation:

Zuena $A R$, lacovelli $L$, Orlando $R$, Di Menna L, Casolini P, Alemà GS,

Di Cicco G, Battaglia G and Nicoletti $F$ (2018) In Vivo Non-radioactive Assessment of mGlu5 Receptor-Activated Polyphosphoinositide Hydrolysis in Response to Systemic Administration of a Positive Allosteric Modulator. Front. Pharmacol. 9:804. doi: 10.3389/fphar.2018.00804
mGlu5 receptor-mediated polyphosphoinositide (PI) hydrolysis is classically measured by determining the amount of radioactivity incorporated in inositolmonophosphate (InsP) after labeling of membrane phospholipids with radioactive inositol. Although this method is historically linked to the study of mGlu receptors, it is inappropriate for the assessment of mGlu5 receptor signaling in vivo. Using a new ELISA kit we showed that systemic treatment with the selective positive allosteric modulator (PAM) of mGlu5 receptors VU0360172 enhanced InsP formation in different brain regions of CD1 or C57Black mice. The action of VU0360172 was sensitive to the mGlu5 receptor, negative allosteric modulator (NAM), MTEP, and was abolished in mice lacking mGlu5 receptors. In addition, we could demonstrate that endogenous activation of mGlu5 receptors largely accounted for the basal PI hydrolysis particularly in the prefrontal cortex. This method offers opportunity for investigation of mGlu5 receptor signaling in physiology and pathology, and could be used for the functional screening of mGlu5 receptor PAMs in living animals.

Keywords: mGlu5 receptors, receptor signaling, polyphosphoinositide hydrolysis, InsP levels, VU0360172, MTEP

\section{INTRODUCTION}

mGlu5 metabotropic glutamate receptors are coupled to $\mathrm{G}_{\mathrm{q} / 11}$, and their activation stimulates phospholipase-C-mediated polyphosphoinositide (PI) hydrolysis with ensuing formation of inositol-1,4,5-trisphosphate ( $\mathrm{InsP}_{3}$ ) and diacylglycerol (reviewed by Nicoletti et al., 2011). mGlu5 receptors play a key role in mechanisms of activity-dependent synaptic plasticity and are promising candidate drug targets for neuroprotective drugs (reviewed by Bruno et al., 2017). Selective ligands of mGlu5 receptors (both positive and negative allosteric modulators) are under development for the treatment of numerous CNS disorders, such as unipolar depression, obsessive-compulsive disorder, schizophrenia, autism, chronic pain, and Parkinson's disease (Vinson and Conn, 2012; Nicoletti et al., 2015; Bruno et al., 2017; Rutrick et al., 2017). This raises the interest on how expression and function of mGlu5 receptors change during CNS development (Minakami et al., 1995; Casabona et al., 1997), in association with learning and memory processes 
(Riedel et al., 2000), in response to stress (Zuena et al., 2008; Yim et al., 2012), and under pathological conditions. Abnormalities in the expression or function of mGlu5 receptors have been associated with schizophrenia (Ohnuma et al., 1998; Gupta et al., 2005; Matosin et al., 2013, 2015; Fatemi and Folsom, 2015; Lum et al., 2017; Zurawek et al., 2017), focal cortical dysplasia (DuBois et al., 2016), absence epilepsy (D'Amore et al., 2015), Down's syndrome (Iyer et al., 2014), neuropathic pain (Lin et al., 2015), Fragile-X syndrome, and other types of monogenic autism (Huber et al., 2002; Bear et al., 2004; Giuffrida et al., 2005; Ronesi et al., 2012; Pignatelli et al., 2014).

Most of the studies investigating mGlu5 receptor-mediated PI hydrolysis have been performed in ex vivo systems, i.e., in brain slices preloaded with $\left[{ }^{3} \mathrm{H}\right]$-myo-D-inositol and challenged with the mGlu1/5 receptor agonist, 3,5-dihydroxyphenylglycine (DHPG). Radioactive inositol is incorporated into inositol phospholipids, and stimulation of PI hydrolysis is routinely assessed by measuring the amount of radioactive inositol monophosphate (InsP, a degradation product of $\mathrm{InsP}_{3}$ ) after blocking its conversion into free inositol with lithium ions. Although this method is informative and is linked to the first descriptions of mGlu receptors (Sladeczek et al., 1985; Nicoletti et al., 1986), it incorporates a number of biases that preclude an accurate analysis of how mGlu5 receptors signal in physiological and pathological conditions. For example, (i) tissue from 4 to 10 rats or mice (depending on the brain region) must be pooled for slice preparation; (ii) the uncontrolled extracellular concentrations of endogenous glutamate in brain slice preparations renders this model inappropriate for the study of the action of different classes of positive allosteric modulators (PAMs) on native mGlu5 receptors; (iii) measurements of radioactive InsP are routinely performed by anion exchange chromatography followed by radioactivity counting with no information on endogenous InsP levels (and, therefore, on the specific activity of $\left[{ }^{3} \mathrm{H}\right]-\mathrm{Ins} \mathrm{P}$ ); and, (iv) when applied to in vivo studies the method requires the intracerebral injection of radioactive inositol.

Here, we demonstrate that it is possible to assess mGlu5 receptor-mediated PI hydrolysis in mice systemically injected with lithium ions followed by a selective mGlu5 receptor PAM by using the Cisbio IP-One ELISA kit, which detects endogenous InsP levels (Trinquet et al., 2011). This method may allow a functional analysis of mGlu5 receptor function in all brain regions of individual animals, and may be of great help for the study of the effects of selective ligands on native mGlu5 receptors in physiology and pathology.

\section{MATERIALS AND METHODS}

\section{Animals}

We used adult CD1 or C57Black male mice (7-8 weeks of age) obtained from Charles River (Calco, Italy), and mGlu5 receptor knockout ( $\mathrm{mGlu}^{-/-}$) mice, obtained by heterozygous breeding (B6;129-Grm5tm1Rod/J, Stock No: 003558, originally purchased from Jackson Laboratory, Bar Harbor, ME, United States). All mice were individually genotyped for the mGlu5 receptor gene by polymerase chain reaction to identify wild-type, heterozygous and knockout mice. All mice were housed in a controlledtemperature room $\left(21-23^{\circ} \mathrm{C}\right.$, humidity $\left.40-50 \%\right)$ and maintained on a 12-h light/dark cycle with food and water ad libitum. All efforts were made to minimize the number of animals used and to alleviate their discomfort. All experimental procedures were performed in conformity with the Italian (D.L. 26/2014) and European Union Directive (2010/63/EU) on the protection of animals used for scientific purposes. Experiments were approved by the Italian Ministry of Health.

\section{Drugs and Treatments}

Experiments were carried out in mice pretreated with lithium chloride. This pretreatment was expected to amplify receptor agonist-stimulated InsP formation owing to the ability of lithium to inhibit the conversion of InsP into free inositol (Berridge et al., 1982). Lithium chloride was purchased from Sigma-Aldrich (Milan, Italy), VU0360172 [N-cyclobutyl-6-(2-(3-fluorophenyl)ethynyl) pyridine-3-carboxamide] and MTEP 3-[(2-methyl-1,3-thiazol-4yl)ethynyl]pyridine hydrochloride were purchased from Tocris Bioscience (Bristol, United Kingdom). Lithium chloride was dissolved in saline, VU0360172 and MTEP were dissolved in 10\% Tween 80 and adjusted to $\mathrm{pH} 7.4$ with $\mathrm{NaOH}$. Drugs and vehicles were administered i.p. in a volume of $5 \mathrm{ml} / \mathrm{kg}$ body weight.

Doses used for VU0360172 and MTEP were selected on the basis of behavioral data in mice (Rodriguez et al., 2010; Hughes et al., 2013; Domin et al., 2014). Mice were treated with lithium chloride ( 2.5 or $10 \mathrm{mmol} / \mathrm{kg}$, corresponding to 105 or $420 \mathrm{mg} / \mathrm{kg}$ ) and, $1 \mathrm{~h}$ later, with VU0360172 (0.3, 3, or $30 \mathrm{mg} / \mathrm{kg})$ and/or MTEP (10 mg/kg), or their vehicles. Two additional groups of CD1 mice were treated i.p. with either VU0360172 $(30 \mathrm{mg} / \mathrm{kg})$ or its vehicle without pretreatment with lithium chloride. One hour after drug injections, mice were killed by decapitation, and the prefrontal cortex, hippocampus, corpus striatum, hypothalamus, olfactory bulbs, and cerebellum were rapidly dissected and stored at $-80^{\circ} \mathrm{C}$ until InsP measurements.

\section{Tissue Preparation and ELISA Measurement of InsP Levels}

Frozen tissue was weighed and homogenized by sonication in $10 \mu \mathrm{l} / \mathrm{mg}$ of tissue of Tris- $\mathrm{HCl}$ buffer (100 mM; pH 7.5)

TABLE 1 | Basal levels of endogenous InsP in different brain regions of CD1 mice.

\begin{tabular}{lc}
\hline Brain regions & InsP levels (nM) \\
\hline Hippocampus & $6950 \pm 244$ \\
Prefrontal cortex & $17215 \pm 1148^{*}$ \\
Striatum & $6446 \pm 601$ \\
Hypothalamus & $4124 \pm 238$ \\
Olfactory bulb & $4349 \pm 288$ \\
Cerebellum & $1154 \pm 213$
\end{tabular}

Mice were treated i.p. with $10 \mathrm{mmol} / \mathrm{kg}$ of lithium chloride, followed, one hour later, by the vehicle of VU0360172. Mice were killed 1 hour after the vehicle (i.e., 2 hours after lithium chloride). Values are means \pm S. E.M. of 5-12 mice per group. * $p<0.05$ vs. all other brain regions (One-way ANOVA + Fisher's LSD; $F_{(5,57)}=73.39$ ). 


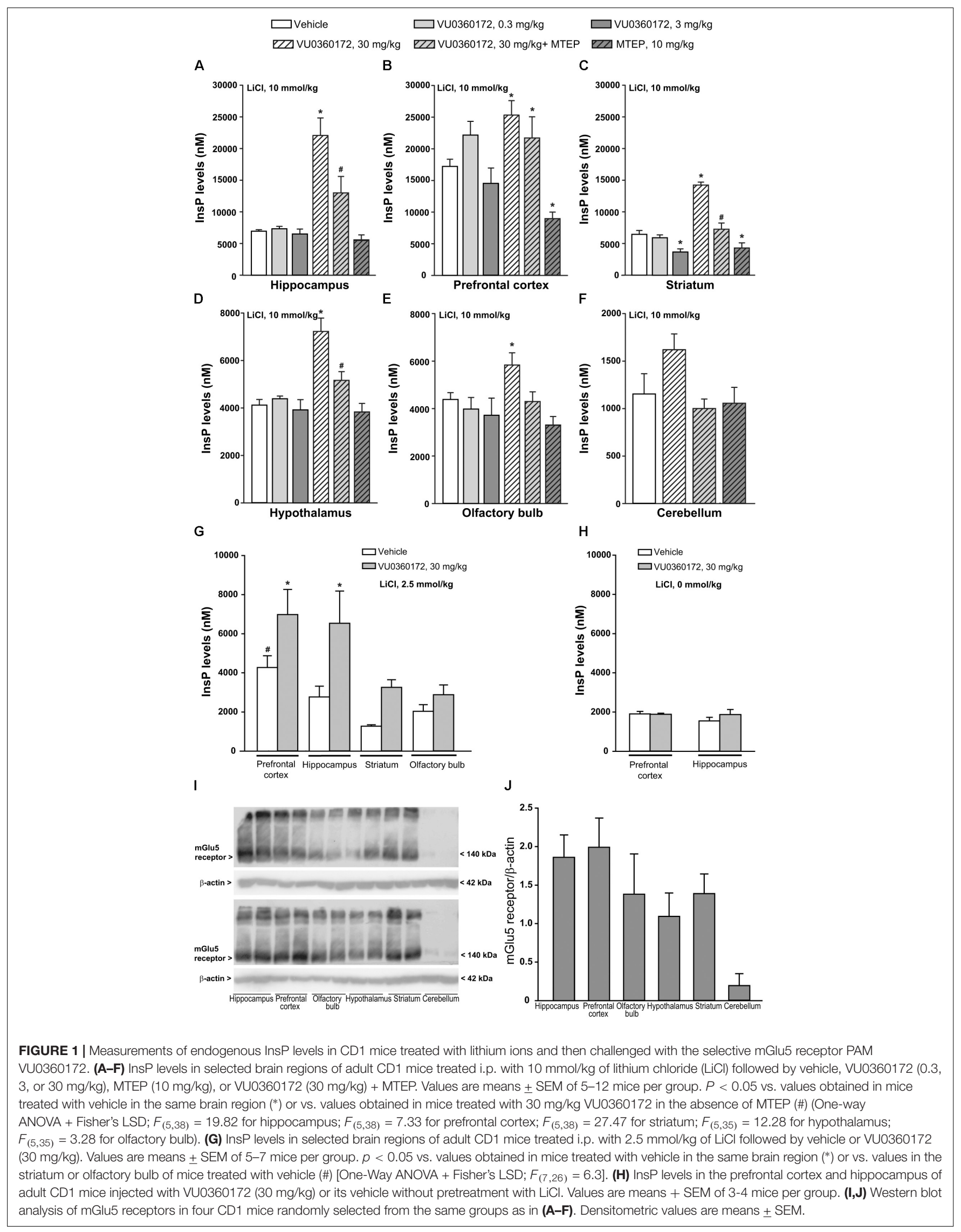


containing $150 \mathrm{mM} \mathrm{NaCl}, 5 \mathrm{mM}$ EDTA, 1\% Triton X-100, 1\% SDS. Homogenates were diluted 1:50 and InsP levels were assessed with the IP-One ELISA kit (Cisbio, Codolet, France) according to the manufacturer's instructions. Mean intra-assay and inter-assay coefficients of variation were 4.68 and $4.83 \%$, respectively.

\section{Immunoblotting}

Western blot analysis of mGlu5 receptors was carried out in the hippocampus, prefrontal cortex, corpus striatum, olfactory bulb, hypothalamus, and cerebellum of four CD1 mice randomly selected from the groups used for the assessment of PI hydrolysis. An aliquot of tissue extract was added with protease inhibitors cocktail (Sigma-Aldrich, Cat. \# 2714) and after protein determination, protein lysates $(40 \mu \mathrm{g})$ were separated by SDSPAGE electrophoresis and blotted onto nitrocellulose. The upper part of the membrane was probed with polyclonal antimGlu5 receptor antibody (Millipore, CA, United States, Cat. \# AB5675, 1:3,000 dilution), and the lower part of the membrane was probed with monoclonal anti- $\beta$-actin antibody (SigmaAldrich, Cat. \# A2228, 1:10,000 dilution). Immunoreactive bands were visualized by enhanced chemilumiscence (Westar, Nova 2011, Cyanagen, Bologna, Italy) using horseradish peroxidaseconjugated secondary antibodies. Densitometric analysis of the immunoreactive bands was performed by Image $\mathrm{J}(\mathrm{NIH}$, Bethesda, MD, United States).

\section{RESULTS}

\section{In Vivo Assessment of mGlu5 Receptor-Mediated PI Hydrolysis in Different Mouse Brain Regions}

To examine whether an enhanced formation of InsP could be detected after systemic treatment with a selective mGlu5 receptor PAM, we used six groups of CD1 mice treated with vehicle, VU0360172 (0.3, 3, or $30 \mathrm{mg} / \mathrm{kg})$, MTEP (10 mg/kg), or VU0360172 (30 mg/kg) + MTEP, respectively. All mice received a single injection of $\mathrm{LiCl}(10 \mathrm{mmol} / \mathrm{kg}) 1 \mathrm{~h}$ prior to drug administrations to inhibit the conversion of InsP into free inositol. Measurements of endogenous InsP levels were carried out in tissue extracts prepared from the prefrontal cortex, hippocampus, corpus striatum, hypothalamus, olfactory bulbs, and cerebellum. Basal InsP levels (i.e., levels detected in mice treated with vehicle) were not homogeneous in the selected brain regions and were substantially higher in the prefrontal cortex than in all other regions (Table 1). This might reflect a high level of endogenous activation or a constitutive activity of mGlu5 receptors because InsP levels in the prefrontal cortex were halved by treatment with the mGlu5 receptor NAM, MTEP (Figure 1B).

The highest dose of the mGlu5 receptor PAM, VU0360172 (30 mg/kg), enhanced InsP levels by $>3$ fold in the hippocampus Figure 1A, by about twofold in the striatum (Figure 1C), and to a lower extent in the other brain regions (Figures 1D-F). Stimulation was negligible in the cerebellum (Figure 1F). In the prefrontal cortex of CD1 mice, VU0360172 treatment caused a small, albeit significant, increase in InsP formation, perhaps because of the high basal noise (Figure 1B). At doses of 0.3 or $3 \mathrm{mg} / \mathrm{kg}$, VU0360172 failed to induce detectable changes in endogenous InsP levels (Figures 1A-E).

Stimulation of PI hydrolysis by VU0360172 was largely reduced by MTEP in the hippocampus, striatum, hypothalamus, and olfactory bulb (Figures 1A,C-E). Unexpectedly, in the prefrontal cortex co-treatment with VU0360172 and MTEP raised InsP levels by $>2$ fold as compared to values obtained with MTEP alone (Figure 1B).

We then examined the effect of VU0360172 in CD1 mice by lowering the dose of $\mathrm{LiCl}$ from 10 to $2.5 \mathrm{mmol} / \mathrm{kg}$ (corresponding to $105 \mathrm{mg} / \mathrm{kg}$ ). Basal InsP levels were reduced in all selected brain regions, particularly in the prefrontal cortex where basal levels were about $20 \%$ of those found with $10 \mathrm{mmol} / \mathrm{kg}$ (compare Figures 1A-C,E with Figure 1G). In mice treated with $2.5 \mathrm{mmol} / \mathrm{kg}$ of $\mathrm{LiCl} \mathrm{VU0360172}(30 \mathrm{mg} / \mathrm{kg})$ stimulated InsP formation in the hippocampus, prefrontal cortex, and corpus striatum, but not in the olfactory bulb (Figure 1G). In the prefrontal cortex, the extent of stimulation was greater in mice treated with $2.5 \mathrm{mmol} / \mathrm{kg}$ than in mice treated with $10 \mathrm{mmol} / \mathrm{kg}$ (62 vs. 32\%) because of a higher signal-to-noise ratio (Figure 1G). In an additional experiment, two groups of mice were treated with $30 \mathrm{mg} / \mathrm{kg}$ of VU0360172 or its vehicle without pre-treatment with $\mathrm{LiCl}$. Basal InsP levels were further reduced in the prefrontal

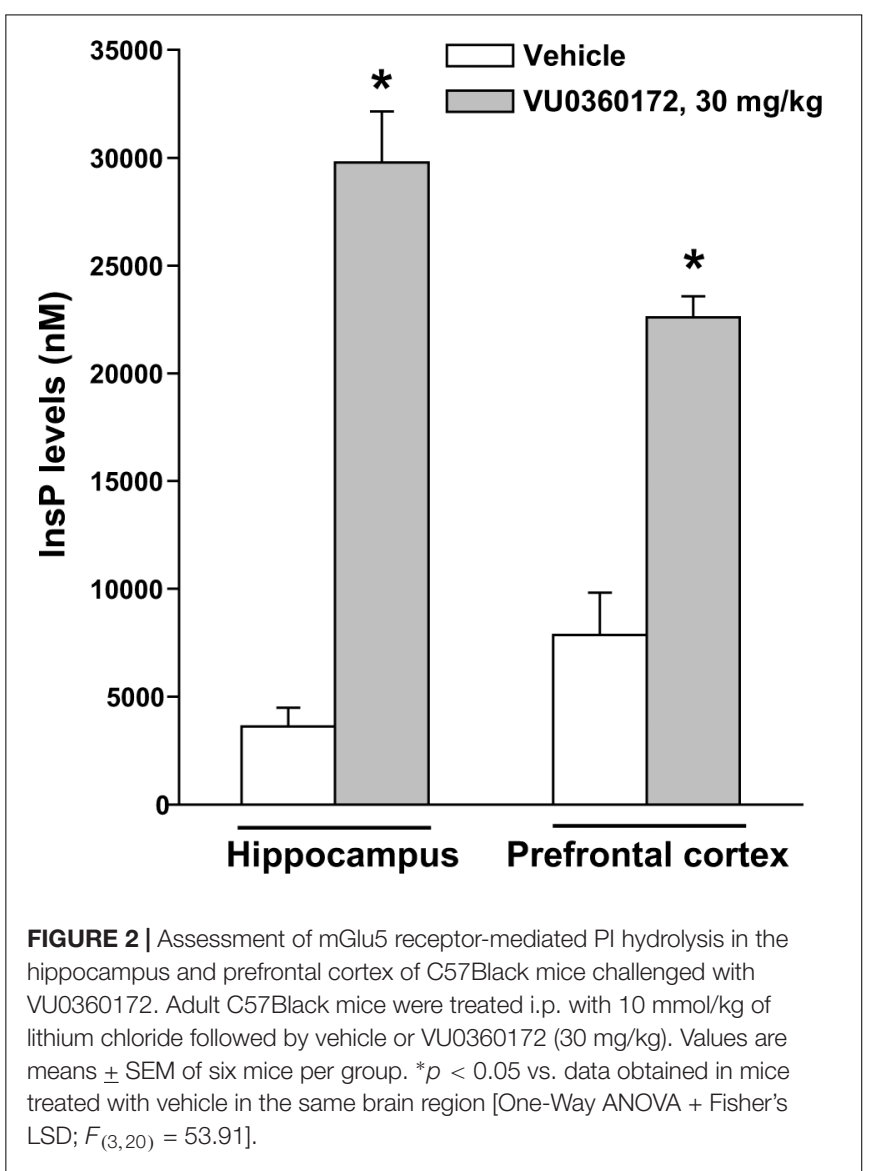




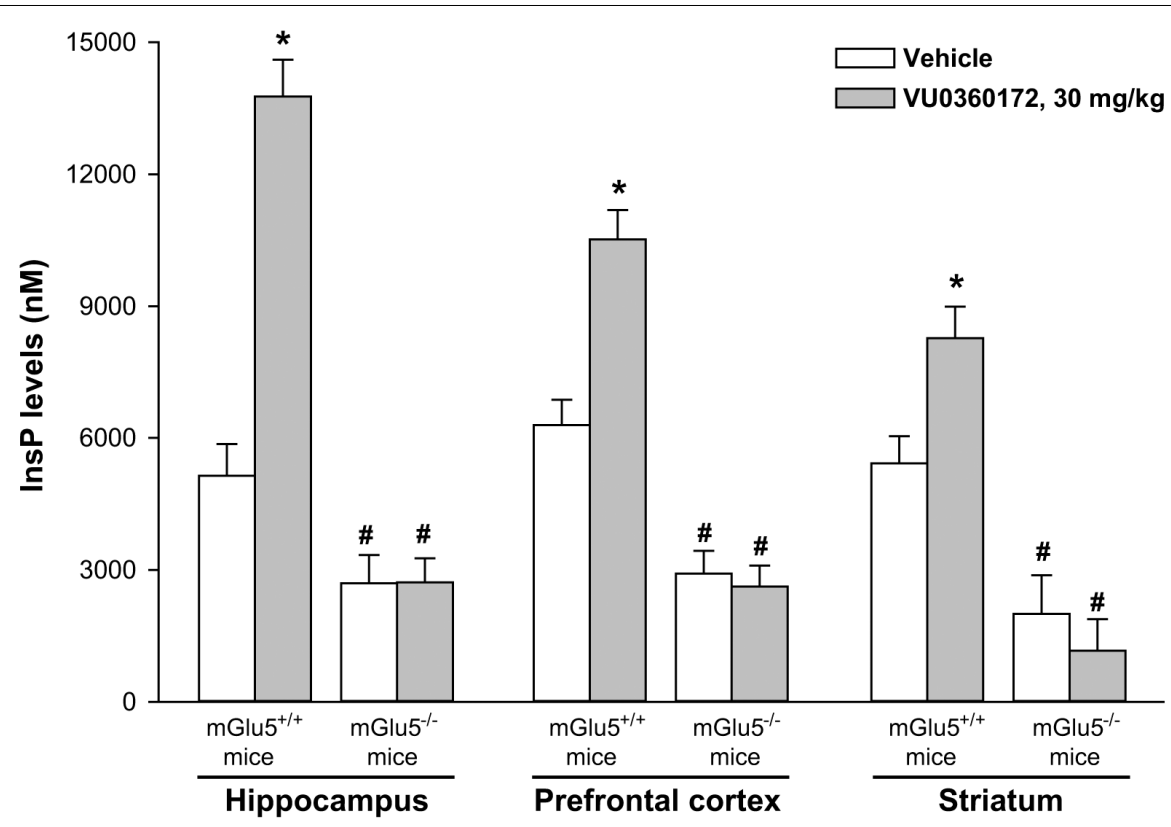

FIGURE 3 | Systemic treatment with VU0360172 failed to stimulate PI hydrolysis in the hippocampus, prefrontal cortex and striatum of mice lacking mGlu5 receptors. $\mathrm{mGlu}^{+/+}$and $\mathrm{mGlu5} /-$ mice were treated with $10 \mathrm{mmol} / \mathrm{kg}$ of lithium chloride followed by either vehicle or VU0360172 (30 mg/kg). Values are means \pm SEM of 3-6 mice for the prefrontal cortex, 3-7 mice for the hippocampus and $2-4$ mice for the striatum $p<0.05$ vs. the respective groups of vehicle-treated mice $\left(^{*}\right)$ or vs. the respective groups of mGlu5 $+/+$ mice $(\#)$ Two-way ANOVA + Fisher's LSD; $F_{(1,15)}=94.99$ for hippocampus; $F_{(1,14)}=99.51$ for prefrontal cortex; $F_{(1,8)}=51.15$ for striatum].

cortex and hippocampus, as compared to values obtained after pretreatment with $2.5 \mathrm{mmol} / \mathrm{kg}$ of $\mathrm{LiCl}$ (compare Figure 1G and Figure 1H). Treatment with VU0360172 failed to enhance InsP formation in mice that had not been pretreated with $\mathrm{LiCl}$ (Figure 1H). The dependence on lithium on basal and agoniststimulated InsP accumulation was expected on the basis of previous results obtained in mice challenged with muscarinic cholinergic receptor agonists (Popiolek et al., 2016). In four $\mathrm{CD} 1$ mice randomly selected from those used for the assessment of PI hydrolysis we examined mGlu5 receptor protein levels. Immunoblots showed a band at about $140 \mathrm{kDa}$ corresponding to receptor monomers, and a higher size molecular band corresponding to receptor dimers. mGlu5 receptor protein levels were higher in the hippocampus and prefrontal cortex, followed by corpus striatum, hypothalamus, and olfactory bulbs, although there was no significant difference among the various brain regions (Figures 1I,J). Protein levels were very low in the cerebellum, as expected (Abe et al., 1992) (Figures 1I,J).

To examine whether mGlu5 receptor-mediated PI hydrolysis in vivo was strain-dependent, we also treated C57Black mice with VU0360172 $(30 \mathrm{mg} / \mathrm{kg})$ and measured InsP levels in the hippocampus and prefrontal cortex. In the hippocampus of C57Black mice VU0360172 stimulated InsP formation by as much as sevenfold. In the prefrontal cortex, basal InsP levels were higher than in the hippocampus. However, treatment with VU0360172 enhanced InsP formation by almost threefold (Figure 2). Thus, the extent of mGlu5 receptor-mediated PI hydrolysis was greater in C57Black mice than in CD1 mice.

\section{VU0360172-Stimulated PI Hydrolysis in Vivo Was Abrogated in Mice With Genetic Deletion of mGlu5 Receptors}

To further demonstrate that VU0360172 was able to stimulate PI hydrolysis in vivo through the activation of mGlu5 receptors, we performed experiments in mGlu5 receptor knockout mice $\left(\mathrm{mGlu}^{-/-}\right)$and their wild-type littermates $\left(\mathrm{mGlu}^{+/+}\right)$. All mice were obtained by heterozygous breeding. As expected, treatment with VU0360172 $(30 \mathrm{mg} / \mathrm{kg})$ significantly increased the InsP formation in the hippocampus, prefrontal cortex and striatum of $\mathrm{mGlu}^{+/+}$mice. In contrast, treatment with VU0360172 failed to stimulate PI hydrolysis in $\mathrm{mGlu}^{-/-}$ mice (Figure 3). In $\mathrm{mGlu}^{-/-}$mice treated with vehicle, InsP levels were significantly reduced in the striatum and showed a trend to reduction in the prefrontal cortex and hippocampus, as compared to their wild-type counterparts (Figure 3). This suggests that endogenous activation of mGlu5 receptors contributes to basal PI hydrolysis in the mouse brain.

\section{DISCUSSION}

We have shown for the first time that it is possible to measure mGlu5 receptor-mediated PI hydrolysis in animals in response to a PAM with a high specificity and a high level of reproducibility. This represents a step forward with respect to conventional measurements of mGlu5 receptor signaling radioactive inositol. The method allows measurements of endogenous InsP levels and optimizes the use of animals without the need of pooling 
brain tissue. This method might be particularly appropriate for the assessment of mGlu5 receptor signaling in a variety of physiological and pathological conditions, and for the study of the action of different chemotypes of PAMs on native mGlu5 receptors. We find particularly attractive the possibility of directly analyzing mGlu5 receptor signaling in response to different classes of PAMs in relation to brain activation, as occurs during the execution of cognitive tasks. This information can be particularly valuable from a clinical standpoint considering that mGlu5 PAMs are under development for the treatment of schizophrenia (Foster and Conn, 2017; Maksymetz et al., 2017).

We were intrigued from the finding that basal PI hydrolysis (i.e., endogenous InsP levels determined in control mice) was not uniform in different brain regions, and was higher in the prefrontal cortex regardless of the strain of mice. Endogenous activation or constitutive activity of mGlu5 receptors accounted for the high basal InsP levels in the prefrontal cortex, because levels were largely reduced by MTEP or by genetic deletion of mGlu5 receptors. The functional partnership between NMDA and mGlu5 receptors might explain the high endogenous activity of mGlu5 receptors in the prefrontal cortex. NMDA and mGlu5 receptors are physically linked by a chain of scaffolding proteins, which include PSD-95, Shank, and Homer (Tu et al., 1999). On the one side, activation of mGlu5 receptors facilitates NMDA receptor function by relieving the $\mathrm{Mg}^{2+}$ blockade of the NMDA-gated ion channel (Doherty et al., 1997; Ugolini et al., 1997; Tu et al., 1999; Awad et al., 2000; Attucci et al., 2001; Mannaioni et al., 2001; Pisani et al., 2001); on the other side, activation of NMDA receptors facilitates mGlu5 receptor activity by limiting mGlu5 receptor desensitization as a result of protein phosphatase-2B-mediated receptor dephosphorylation (Alagarsamy et al., 2005). At least in one population of prefrontal cortical GABAergic interneurons, the fast-spiking parvalbumin-positive interneurons, NMDA receptors are highly expressed and are tonically active because of the more depolarized state of these neurons (Homayoun and Moghaddam, 2007; Moghaddam and Javitt, 2012; RosenthalSimons et al., 2013). mGlu5 receptors are also present in parvalbumin-positive interneurons and parvalbumin-cell ablation of either NMDA or mGlu5 receptors alters the development and function of these neurons inducing core features of schizophrenia and other neurodevelopmental disorders (Belforte et al., 2010; Billingslea et al., 2014; Barnes et al., 2015). It is possible that the tonic activity of NMDA receptors in prefrontal cortical interneurons enhances the endogenous activation of mGlu5 receptors, accounting for the high mGlu5-dependent basal PI hydrolysis we have seen in the mouse prefrontal cortex. It will be interesting to examine how basal prefrontal cortical PI hydrolysis changes after conditional ablation of NMDA receptors in GABAergic interneurons or in response to treatments with NMDA receptor blockers, such as ketamine or phencyclidine.

To pharmacologically activate mGlu5 receptors we used the compound VU0360172 which displays high potency $\left(\mathrm{EC}_{50}\right.$ value in the low nanomolar range) and selectivity as mGlu5 receptor PAM (Rodriguez et al., 2010). VU0360172 interacts with the FBEP/MPEP allosteric site of mGlu5 receptors (Rook et al., 2015), and behaves as a PAM with low agonist activity (Sengmany et al., 2017). VU0360172 stimulated PI hydrolysis at the dose of $30 \mathrm{mg} / \mathrm{kg}$, but not at lower doses, in agreement with the dose response effect of the drug in behavioral studies (Rodriguez et al., 2010). VU0360172 stimulated PI hydrolysis to a different extent in the six selected brain regions, with the greatest PI response being observed in the hippocampus and the lowest response in the cerebellum. In CD1 mice, this roughly correlated with the expression levels of mGlu5 receptors, taking into account that the response to VU0360172 in the prefrontal cortex might be underestimated because of the high level of endogenous activation of mGlu5 receptors. We were surprised to find that the mGlu5 NAM MTEP was unable to antagonize the stimulation of InsP formation by VU0360172 in the prefrontal cortex whereas it was effective in the other brain regions. Perhaps in the prefrontal cortex mGlu5 receptors are highly activated by a mechanism of receptor-receptor interaction with NMDA receptors, and, under these conditions, receptors affinity for VU0360172 increases and the drug is no longer displaced by MTEP (at least at the doses used in the present study). It will be interesting to examine whether both basal and VU0360172-stimulated PI hydrolysis in the prefrontal cortex are affected by NMDA receptor blockers. The PI response to VU0360172 in CD1 mice was greater in the striatum than in the hypothalamus and olfactory bulb in spite of the comparable expression levels of mGlu5 receptors in the three regions. This might reflect differences in the efficiency of receptor coupling or in the physiological pattern of receptor activation.

\section{CONCLUSION}

This new method for non-radioactive, in vivo assessment of mGlu5 receptor-mediated PI hydrolysis might offer opportunity for the investigation of how mGlu5 receptor signaling changes in relation to network activity and processes of activity-dependent synaptic plasticity, as well as in pathological conditions. Mouse models of monogenic autism are just an example of the multitude of potential applications of this method (see section "Introduction" and "References" therein). In addition, the method may be particularly advantageous for the screening of mGlu5 receptor PAMs in living animals, providing accurate information of how different classes of PAMs influence receptor function in different brain regions.

\section{AUTHOR CONTRIBUTIONS}

AZ, GA, GDC, LDM, LI, and RO performed experiments on in vivo PI hydrolysis and Western Blotting. AZ, GB, and LDM analyzed the data. AZ, GB, PC, and FN designed the research and wrote the manuscript.

\section{FUNDING}

This work was supported by PC grant (Sapienza, Ateneo 2014). 


\section{REFERENCES}

Abe, T., Sugihara, H., Nawa, H., Shigemoto, R., Mizuno, N., and Nakanishi, S. (1992). Molecular characterization of a novel metabotropic glutamate receptor mGluR5 coupled to inositol phosphate/ $\mathrm{Ca}^{2+}$ signal transduction. J. Biol. Chem. 267, 13361-13368.

Alagarsamy, S., Saugstad, J., Warren, L., Mansuy, I. M., Gereau, R. W. IV, and Conn, P. J. (2005). NMDA-induced potentiation of mGluR5 is mediated by activation of protein phosphatase 2B/calcineurin. Neuropharmacology 49, 135-145. doi: 10.1016/j.neuropharm.2005.05.005

Attucci, S., Carlà, V., Mannaioni, G., and Moroni, F. (2001). Activation of type 5 metabotropic glutamate receptors enhances NMDA responses in mice cortical wedges. Br. J. Pharmacol. 132, 799-806. doi: 10.1038/sj.bjp.070 3904

Awad, H., Hubert, G. W., Smith, Y., Levey, A. I., and Conn, P. J. (2000). Activation of metabotropic glutamate receptor 5 has direct excitatory effects and potentiates NMDA receptor currents in neurons of the subthalamic nucleus. J. Neurosci. 20, 7871-7879. doi: 10.1523/JNEUROSCI.20-21-07871. 2000

Barnes, S. A., Pinto-Duarte, A., Kappe, A., Zembrzycki, A., Metzler, A., Mukamel, E. A., et al. (2015). Disruption of mGluR5 in parvalbumin-positive interneurons induces core features of neurodevelopmental disorders. Mol. Psychiatry 20, 1161-1172. doi: 10.1038/mp.2015.113

Bear, M. F., Huber, K. M., and Warren, S. T. (2004). The mGluR theory of fragile X mental retardation. Trends Neurosci. 27, 370-377. doi: 10.1016/j.tins.2004. 04.009

Belforte, J. E., Zsiros, V., Sklar, E. R., Jiang, Z., Yu, G., Li, Y., et al. (2010). Postnatal NMDA receptor ablation in corticolimbic interneurons confers schizophrenialike phenotypes. Nat. Neurosci. 13, 76-83. doi: 10.1038/nn.2447

Berridge, M. J., Downes, C. P., and Hanley, M. R. (1982). Lithium amplifies agonist-dependent phosphatidylinositol responses in brain and salivary glands. Biochem. J. 206, 587-595.

Billingslea, E. N., Tatard-Leitman, V. M., Anguiano, J., Jutzeler, C. R., Suh, J., Saunders, J. A., et al. (2014). Parvalbumin cell ablation of NMDA-R1 causes increased resting network excitability with associated social and selfcare deficits. Neuropsychopharmacology 39, 1603-1613. doi: 10.1038/npp 2014.7

Bruno, V., Caraci, F., Copani, A., Matrisciano, F., Nicoletti, F., and Battaglia, G. (2017). The impact of metabotropic glutamate receptors into active neurodegenerative processes: a "dark side" in the development of new symptomatic treatments for neurologic and psychiatric disorders. Neuropharmacology 115, 180-192. doi: 10.1016/j.neuropharm.2016.04.044

Casabona, G., Knöpfel, T., Kuhn, R., Gasparini, F., Baumann, P., Sortino, M. A., et al. (1997). Expression and coupling to polyphosphoinositide hydrolysis of group I metabotropic glutamate receptors in early postnatal and adult rat brain. Eur. J. Neurosci. 9, 12-17. doi: 10.1111/j.1460-9568.1997. tb01348.x

D’Amore, V., von Randow, C., Nicoletti, F., Ngomba, R. T., and van Luijtelaar, G. (2015). Anti-absence activity of mGlu1 and mGlu5 receptor enhancers and their interaction with a GABA reuptake inhibitor: effect of local infusions in the somatosensory cortex and thalamus. Epilepsia 56, 1141-1151. doi: 10.1111/epi. 13024

Doherty, A. J., Palmer, M. J., Henley, J. M., Collingridge, G. L., and Jane, D. E. (1997). (RS)-2-chloro-5-hydroxyphenylglycine (CHPG) activates mGlu5, but no mGlu1, receptors expressed in CHO cells and potentiates NMDA responses in the hippocampus. Neuropharmacology 36, 265-267. doi: 10.1016/S00283908(97)00001-4

Domin, H., Szewczyk, B., Woźniak, M., Wawrzak-Wlecial, A., and Śmialowska, M. (2014). Antidepressant-like effect of the mGluR5 antagonist MTEP in an astroglial degeneration model of depression. Behav. Brain Res. 273, 23-33. doi: 10.1016/j.bbr.2014.07.019

DuBois, J. M., Rousset, O. G., Guiot, M. C., Hall, J. A., Reader, A. J., Soucy, J. P., et al. (2016). Metabotropic glutamate receptor type 5 (mGluR5) cortical abnormalities in focal cortical dysplasia identified in vivo With [11C]ABP688 Positron-Emission Tomography (PET) imaging. Cereb. Cortex 26, 4170-4179. doi: 10.1093/cercor/bhw249

Fatemi, S. H., and Folsom, T. D. (2015). GABA receptor subunit distribution and FMRP-mGluR5 signaling abnormalities in the cerebellum of subjects with schizophrenia, mood disorders, and autism. Schizophr. Res. 167, 42-56. doi: 10.1016/j.schres.2014.10.010

Foster, D. J., and Conn, P. J. (2017). Allosteric modulation of GPCRs: new insights and potential utility for treatment of schizophrenia and other CNS disorders. Neuron 94, 431-446. doi: 10.1016/j.neuron.2017.03.016

Giuffrida, R., Musumeci, S., D’Antoni, S., Bonaccorso, C. M., Giuffrida-Stella, A. M., Oostra, B. A., et al. (2005). A reduced number of metabotropic glutamate subtype 5 receptors are associated with constitutive homer proteins in a mouse model of fragile X syndrome. J. Neurosci. 25, 8908-8916. doi: 10.1523/ JNEUROSCI.0932-05.2005

Gupta, D. S., McCullumsmith, R. E., Beneyto, M., Haroutunian, V., Davis, K. L., and Meador-Woodruff, J. H. (2005). Metabotropic glutamate receptor protein expression in the prefrontal cortex and striatum in schizophrenia. Synapse 57, 123-131. doi: 10.1002/syn.20164

Homayoun, H., and Moghaddam, B. (2007). NMDA receptor hypofunction produces opposite effects on prefrontal cortex interneurons and pyramidal neurons. J. Neurosci. 27, 11496-11500. doi: 10.1523/JNEUROSCI.2213-07. 2007

Huber, K. M., Gallagher, S. M., Warren, S. T., and Bear, M. F. (2002). Altered synaptic plasticity in a mouse model of fragile $\mathrm{X}$ mental retardation. Proc. Natl. Acad. Sci. U.S.A. 99, 7746-7750. doi: 10.1073/pnas.12220 5699

Hughes, Z. A., Neal, S. J., Smith, D. L., Sukoff Rizzo, S. J., Pulicicchio, C. M. Lotarski, S., et al. (2013). Negative allosteric modulation of metabotropic glutamate receptor 5 results in broad spectrum activity relevant to treatment resistant depression. Neuropharmacology 66, 202-214. doi: 10.1016/ j.neuropharm.2012.04.007

Iyer, A. M., van Scheppingen, J., Milenkovic, I., Anink, J. J., Lim, D., Genazzani, A. A., et al. (2014). Metabotropic glutamate receptor 5 in down's syndrome hippocampus during development: increased expression in astrocytes. Curr. Alzheimer Res. 11, 694-705. doi: 10.2174/156720501166614081211 5423

Lin, T. B., Lai, C. Y., Hsieh, M. C., Wang, H. H., Cheng, J. K., Chau, Y. P., et al. (2015). VPS26A-SNX27 interaction-dependent mGluR5 recycling in dorsal horn neurons mediates neuropathic pain in rats. J. Neurosci. 35, 14943-14955. doi: 10.1523/JNEUROSCI.2587-15.2015

Lum, J. S., Millard, S. J., Huang, X. F., Ooi, L., and Newell, K. A. (2017). A postmortem analysis of NMDA ionotropic and group 1 metabotropic glutamate receptors in the nucleus accumbens in schizophrenia. J. Psychiatry Neurosci. 42:170077.

Maksymetz, J., Moran, S. P., and Conn, P. J. (2017). Targeting metabotropic glutamate receptors for novel treatments of schizophrenia. Mol. Brain 10:15 doi: 10.1186/s13041-017-0293-z

Mannaioni, G., Marino, M. J., Valenti, O., Traynelis, S. F., and Conn, P. J. (2001). Metabotropic glutamate receptors 1 and 5 differentially regulate CA 1 pyramidal cell function. J. Neurosci. 21, 5925-5934. doi: 10.1523/JNEUROSCI.21-1605925.2001

Matosin, N., Fernandez-Enright, F., Lum, J. S., Andrews, J. L., Engel, M., Huang, X. F., et al. (2015). Metabotropic glutamate receptor 5, and its trafficking molecules Norbin and Tamalin, are increased in the CA1 hippocampal region of subjects with schizophrenia. Schizophr. Res. 166, 212-218. doi: 10.1016/j.schres. 2015.05 .001

Matosin, N., Frank, E., Deng, C., Huang, X. F., and Newell, K. A. (2013). Metabotropic glutamate receptor 5 binding and protein expression in schizophrenia and following antipsychotic drug treatment. Schizophr. Res. 146, 170-176. doi: 10.1016/j.schres.2013.01.018

Minakami, R., Iida, K., Hirakawa, N., and Sugiyama, H. (1995). The expression of two splice variants of metabotropic glutamate receptor subtype 5 in the rat brain and neuronal cells during development. J. Neurochem. 65, 1536-1542. doi: 10.1046/j.1471-4159.1995.65041536.x

Moghaddam, B., and Javitt, D. (2012). From revolution to evolution the glutamate hypothesis of schizophrenia and its implication for treatment. Neuropsychopharmacology 37, 4-15. doi: 10.1038/npp.20 11.181

Nicoletti, F., Bockaert, J., Collingridge, G. L., Conn, P. J., Ferraguti, F., Schoepp D. D., et al. (2011). Metabotropic glutamate receptors: from the workbench to the bedside. Neuropharmacology 60, 1017-1041. doi: 10.1016/j.neuropharm. 2010.10.022 
Nicoletti, F., Bruno, V., Ngomba, R. T., Gradini, R., and Battaglia, G. (2015). Metabotropic glutamate receptors as drug targets: What's new? Curr. Opin. Pharmacol. 20, 89-94. doi: 10.1016/j.coph.2014.12.002

Nicoletti, F., Meek, J. L., Iadarola, M. J., Chuang, D. M., Roth, B. L., and Costa, E. (1986). Coupling of inositol phospholipid metabolism with excitatory amino acid recognition sites in rat hippocampus. J. Neurochem. 46, 40-46. doi: 10. 1111/j.1471-4159.1986.tb12922.x

Ohnuma, T., Augood, S. J., Arai, H., McKenna, P. J., and Emson, P. C. (1998). Expression of the human excitatory amino acid transporter 2 and metabotropic glutamate receptors 3 and 5 in the prefrontal cortex from normal individuals and patients with schizophrenia. Brain Res. Mol. Brain Res. 56, 207-217. doi: 10.1016/S0169-328X(98)00063-1

Pignatelli, M., Piccinin, S., Molinaro, G., Di Menna, L., Riozzi, B., Cannella, M., et al. (2014). Changes in mGlu5 receptor-dependent synaptic plasticity and coupling to homer proteins in the hippocampus of Ube3A hemizygous mice modeling angelman syndrome. J. Neurosci. 34, 4558-4566. doi: 10.1523/ JNEUROSCI.1846-13.2014

Pisani, A., Gubellini, P., Bonsi, P., Conquet, F., Picconi, B., Centonze, D., et al. (2001). Metabotropic glutamate receptor 5 mediates the potentiation of $\mathrm{N}$-methyl-D-aspartate responses in medium spiny striatal neurons. Neuroscience 106, 579-587. doi: 10.1016/S0306-4522(01)00297-4

Popiolek, M., Nguyen, D. P., Reinhart, V., Edgerton, J. R., Harms, J., Lotarski, S. M., et al. (2016). Inositol phosphate accumulation in vivo provides a measure of muscarinic $\mathrm{M}_{1}$ receptor activation. Biochemistry 55, 7073-7085. doi: 10.1021/ acs.biochem.6b00688

Riedel, G., Casabona, G., Platt, B., Macphail, E. M., and Nicoletti, F. (2000). Fear conditioning-induced time- and subregion-specific increase in expression of mGlu5 receptor protein in rat hippocampus. Neuropharmacology 39, 1943-1951. doi: 10.1016/S0028-3908(00)00037-X

Rodriguez, A. L., Grier, M. D., Jones, C. K., Herman, E. J., Kane, A. S., Smith, R. L., et al. (2010). Discovery of novel allosteric modulators of metabotropic glutamate receptor subtype 5 reveals chemical and functional diversity and in vivo activity in rat behavioral models of anxiolytic and antipsychotic activity. Mol. Pharmacol. 78, 1105-1123. doi: 10.1124/mol.110.067207

Ronesi, J. A., Collins, K. A., Hays, S. A., Tsai, N. P., Guo, W., Birnbaum, S. G., et al. (2012). Disrupted homer scaffolds mediate abnormal mGluR5 function in a mouse model of fragile X syndrome. Nat. Neurosci. 15, 431-440. doi: 10.1038/nn.3033

Rook, J. M., Tantawy, M. N., Ansari, M. S., Felts, A. S., Stauffer, S. R., Emmitte, K. A., et al. (2015). Relationship between in vivo receptor occupancy and efficacy of metabotropic glutamate receptor subtype 5 allosteric modulators with different in vitro binding profiles. Neuropsychopharmacology 40, 755-765. doi: $10.1038 /$ npp. 2014.245

Rosenthal-Simons, A., Durrant, A. R., and Heresco-Levy, U. (2013). Autoimmuneinduced glutamatergic receptor dysfunctions: conceptual and psychiatric practice implications. Eur. Neuropsychopharmacol. 23, 1659-1671. doi: 10.1016/ j.euroneuro.2013.05.008

Rutrick, D., Stein, D. J., Subramanian, G., Smith, B., Fava, M., Hasler, G., et al. (2017). Mavoglurant augmentation in OCD patients resistant to selective serotonin reuptake inhibitors: a proof-of-concept, randomized, placebocontrolled, phase 2 study. Adv. Ther. 34, 524-541. doi: 10.1007/s12325-0160468-5

Sengmany, K., Singh, J., Stewart, G. D., Conn, P. J., Christopoulos, A., and Gregory, K. J. (2017). Biased allosteric agonism and modulation of metabotropic glutamate receptor 5: implications for optimizing preclinical neuroscience drug discovery. Neuropharmacology 115, 60-72. doi: 10.1016/j.neuropharm.2016. 07.001

Sladeczek, F., Pin, J. P., Récasens, M., Bockaert, J., and Weiss, S. (1985). Glutamate stimulates inositol phosphate formation in striatal neurones. Nature 317, 717-719. doi: 10.1038/317717a0

Trinquet, E., Bouhelal, R., and Dietz, M. (2011). Monitoring Gq-coupled receptor response through inositol phosphate quantification with the IP-One assay. Expert Opin. Drug Discov. 6, 981-994. doi: 10.1517/17460441.2011.60 8658

Tu, J. C., Xiao, B., Naisbitt, S., Yuan, J. P., Petralia, R. S., Brakeman, P., et al. (1999). Coupling of mGluR/Homer and PSD-95 complexes by the Shank family of postsynaptic density proteins. Neuron 23, 583-592. doi: 10.1016/S08966273(00)80810-7

Ugolini, A., Corsi, M., and Bordi, F. (1997). Potentiation of NMDA and AMPA responses by group I mGluR in spinal cord motoneurons. Neuropharmacology 36, 1047-1055. doi: 10.1016/S0028-3908(97)00103-2

Vinson, P. N., and Conn, P. J. (2012). Metabotropic glutamate receptors as therapeutic targets for schizophrenia. Neuropharmacology 62, 1461-1472. doi: 10.1016/j.neuropharm.2011.05.005

Yim, Y. S., Lee, J., Kim, G. T., Song, T., Kim, C. H., and Kim, D. G. (2012). Hippocampal mGluR5 predicts an occurrence of helplessness behavior after repetitive exposure to uncontrollable stress. Neurosci. Lett. 519, 62-66. doi: 10.1016/j.neulet.2012.05.022

Zuena, A. R., Mairesse, J., Casolini, P., Cinque, C., Alemà, G. S., Morley-Fletcher, S., et al. (2008). Prenatal restraint stress generates two distinct behavioral and neurochemical profiles in male and female rats. PLoS One 3:e2170. doi: 10.1371/ journal.pone.0002170

Zurawek, D., Salerno-Kochan, A., Dziedzicka-Wasylewska, M., Nikiforuk, A., Kos, T., and Popik, P. (2017). Changes in the expression of metabotropic glutamate receptor 5 (mGluR5) in a ketamine-based animal model of schizophrenia. Schizophr. Res. 192, 423-430. doi: 10.1016/j.schres.2017.04.014

Conflict of Interest Statement: The authors declare that the research was conducted in the absence of any commercial or financial relationships that could be construed as a potential conflict of interest.

Copyright (๔) 2018 Zuena, Iacovelli, Orlando, Di Menna, Casolini, Alemà, Di Cicco, Battaglia and Nicoletti. This is an open-access article distributed under the terms of the Creative Commons Attribution License (CC BY). The use, distribution or reproduction in other forums is permitted, provided the original author(s) and the copyright owner(s) are credited and that the original publication in this journal is cited, in accordance with accepted academic practice. No use, distribution or reproduction is permitted which does not comply with these terms. 